\title{
The Role of Shadow Friends in Learning Process of Al Islam and Kemuhammadiyahan for Special Needs Student \\ (Case Study in University of Muhammadiyah Jakarta)
}

\author{
Andriyani Asmuni \\ Al-Islam and Kemuhammadiyahan Department \\ Faculty of Medicine and Health, University of Muhammadiyah Jakarta \\ South Tangerang, Indonesia \\ drandriyanimag@gmail.com
}

\begin{abstract}
Abstarct- The problems faced by persons with disabilities are not only in primary education to senior secondary education, but also post secondary education. Formally, access to non-discriminatory education for persons with disabilities has been guaranteed by the Law. Muhammadiyah University of Jakarta as a university in Muhammadiyah affiliation, including one of the institutions that accept students with special needs in several faculties. Special needs students in UMJ are blind students who assisted by shadow friends in the learning process. This study used a descriptive qualitative method. The study was conducted at the University of Muhammadiyah Jakarta in August-October 2017 by conducting interviews and observations. The results are that implementation of AIK at UMJ for special needs students is very important in improving their knowledge and religion. In learning process of AIK, in addition to assisted by lecturers, they are also assisted by other students as a shadow friend. Based on observations, from some educational components that are observed, several of them are not available in UMJ. There is no special quota in the acceptance of special needs students and the number of special needs students at UMJ is still a minority. In the process of identification and assessment including facilities and infrastructure, special needs students are equated with other students. The conclusion is special needs students are not assisted by special supervisors or lecturers but assisted by other students as a shadow friend. The presence of shadow friends is very helpful for the development of special needs students both in terms of AIK assessment and in social life.
\end{abstract}

\section{INTRODUCTION}

The number of persons with disabilities is increasing every year, as recorded in the Central Bureau of Statistics data, which states as many as 9.9 million Indonesian children are children with special needs in the category of persons with disabilities. The Center for Data and Information of the Ministry of Health of the Republic of Indonesia in 2014 also published the number of children with diabilities in Indonesia. Based on Susenas 2012 data, the estimated population in Indonesia with a disability of $2.45 \%$ and about $39.97 \%$ of the number experienced more than one limitation or disability[1].
Disability is defined as the inability to do something like other people do (Hallahan \& Kauffman, 2006). Disability is also a loss of physical function or difficulty in learning or social adjustment that is very influential on growth and development. The cause of disability can come from heredity or the environment, and can also be experienced from before birth or after birth (Hallahan \& Kauffman, 2006).[2] One of the disabilities is blindness.

The problems faced by persons with disabilities are not only in primary education to senior secondary education, but also post secondary education. Formally, access to non-discriminatory education for persons with disabilities is guaranteed by Act Number 20 Year 2003 on National Education System and Regulation of the Minister of National Education Number 70 Year 2009 on Inclusive Education. This policy allows people with disabilities to access education together with general students, according to the ability of persons with disabilities.

In article 1 of the Regulation of the Minister of National Education of the Republic of Indonesia Number 70 of 2009 on Inclusive Education for Educated and Abstinent Students of Potential Intelligence and / or Special Talent states that "Inclusive education is an education system that provides opportunities for all learners who have abnormalities and have the potential of intelligence and / or special talents to follow education or learning in an educational environment together with learners in general. "

University of Muhammadiyah Jakarta as a university in the Muhammadiyah affiliation, including one of the institutions that accept students with special needs in several faculties. The formulation of Muhammadiyah ideology and personality that became the breath in the development of $\mathrm{Al}$ Islam and Muhammadiyah studies (AIK) at UMJ has been very in line with the spirit of PP No. 55 of 2007, and responded positively by UMJ, by giving AIK courses, which are not oriented as media to print religious experts, but to deliver students into Islamic professionals. They are not required to be religious scholars, but they also have a 
commitment to practice religion, not only in the context of ritual acts, but insertion of code of conduct, spirit and Islamic values on professional behavior and social[3].

Special needs students in UMJ are blind students who assisted by shadow friends in their learning process of AIK. UMJ's acceptance of special needs students is quite different from other universities in general. Many things needs attention and need to be prepared in facing the application of education to special needs students, especially in learning AIK. This is the reason for researchers to conduct research on the role of shadow friends on the learning process of $\mathrm{Al}$ Islam and Kemuhammadiyahan for special needs students at UMJ.

\section{METHODS}

In this study, researchers used a descriptive qualitative method. The purpose of this method is to describe and solve problems in a systematic, factual, and accurate[4]. The study was conducted at the University of Muhammadiyah Jakarta in August-October 2017 by conducting interviews and observations. Interviews were conducted on 7 (seven) persons, of whom 2 were lecturers, 3 special needs students, and 2 other students as a shadow friends. The special needs students must be representative of this study.

\section{RESULT}

\section{A. Observation Result}

\begin{tabular}{|c|c|c|c|c|c|}
\hline \multirow[b]{2}{*}{ No. } & \multirow{2}{*}{$\begin{array}{l}\text { Education } \\
\text { Compound }\end{array}$} & \multirow{2}{*}{$\begin{array}{l}\text { Aspects } \\
\text { Observed }\end{array}$} & \multicolumn{2}{|c|}{ Availability } & \multirow[b]{2}{*}{ Information } \\
\hline & & & Available & $\begin{array}{c}\text { Non- } \\
\text { Available }\end{array}$ & \\
\hline \multirow{3}{*}{1.} & \multirow{3}{*}{$\begin{array}{l}\text { Student } \\
\text { affairs }\end{array}$} & \begin{tabular}{lr} 
Special & quota \\
of & special \\
needs & student \\
\multicolumn{2}{l}{ acceptance }
\end{tabular} & & $\sqrt{ }$ & $\begin{array}{l}\text { There are no } \\
\text { special } \\
\text { quotas. }\end{array}$ \\
\hline & & $\begin{array}{l}\text { The process of } \\
\text { identifying and } \\
\text { assessing } \\
\text { special needs } \\
\text { students }\end{array}$ & & $\sqrt{ }$ & $\begin{array}{l}\text { The } \\
\text { identification } \\
\text { and } \\
\text { assessment } \\
\text { process is } \\
\text { equated with } \\
\text { other } \\
\text { students. }\end{array}$ \\
\hline & & $\begin{array}{l}\text { Sheet } \\
\text { identification } \\
\text { and special } \\
\text { needs students } \\
\text { assessment }\end{array}$ & & $\sqrt{ }$ & $\begin{array}{l}\text { Identification } \\
\text { sheets and } \\
\text { assessments } \\
\text { are equated } \\
\text { with other } \\
\text { students. }\end{array}$ \\
\hline \multirow{3}{*}{2.} & \multirow{3}{*}{ Curriculum } & $\begin{array}{l}\text { The curriculum } \\
\text { is developed } \\
\text { with modified } \\
\text { models at the } \\
\text { level, syllabus, } \\
\text { and evaluation }\end{array}$ & $\sqrt{ }$ & & \\
\hline & & $\begin{array}{l}\text { Individual } \\
\text { learning } \\
\text { program }\end{array}$ & & $\sqrt{ }$ & $\begin{array}{l}\text { The learning } \\
\text { process is } \\
\text { equated with } \\
\text { other } \\
\text { students }\end{array}$ \\
\hline & & $\begin{array}{lr}\begin{array}{l}\text { Report on the } \\
\text { assessment of } \\
\text { special } \\
\text { learning } \\
\text { process } \\
\text { special needs }\end{array} \\
\end{array}$ & & $\sqrt{ }$ & $\begin{array}{l}\text { The } \\
\text { assessment } \\
\text { report of the } \\
\text { learning } \\
\text { process is } \\
\text { equated with }\end{array}$ \\
\hline
\end{tabular}

\begin{tabular}{|c|c|c|c|c|c|}
\hline & & students. & & & $\begin{array}{l}\text { other } \\
\text { students }\end{array}$ \\
\hline \multirow[t]{2}{*}{3.} & \multirow[t]{2}{*}{$\begin{array}{l}\text { Lecturers or } \\
\text { Supervisors }\end{array}$} & $\begin{array}{l}\text { Special } \\
\text { lecturers } \\
\text { supervisors }\end{array}$ & & $\sqrt{ }$ & $\begin{array}{l}\text { There is no } \\
\text { special tutor, } \\
\text { but was } \\
\text { replaced by a } \\
\text { shadow } \\
\text { friends. }\end{array}$ \\
\hline & & $\begin{array}{l}\text { Training of } \\
\text { inclusive } \\
\text { education }\end{array}$ & $\sqrt{ }$ & & \\
\hline 4. & $\begin{array}{l}\text { Facilities and } \\
\text { infrastructure }\end{array}$ & $\begin{array}{l}\text { Special } \\
\text { facilities and } \\
\text { infrastructure }\end{array}$ & & $\sqrt{ }$ & $\begin{array}{l}\text { Facilities and } \\
\text { infrastructure } \\
\text { are equated } \\
\text { with other } \\
\text { students. }\end{array}$ \\
\hline \multirow[b]{2}{*}{5.} & \multirow[b]{2}{*}{ Financing } & $\begin{array}{l}\text { Incorporate } \\
\text { inclusive } \\
\text { education. }\end{array}$ & $\sqrt{ }$ & & \\
\hline & & $\begin{array}{l}\text { There is an } \\
\text { additional fee } \\
\text { for lecturers } \\
\text { who also serve } \\
\text { as special } \\
\text { mentors. }\end{array}$ & & $\sqrt{ }$ & $\begin{array}{l}\text { There is no } \\
\text { additional } \\
\text { cost because } \\
\text { there is no } \\
\text { special } \\
\text { supervisors. }\end{array}$ \\
\hline \multirow[t]{2}{*}{6.} & \multirow[t]{2}{*}{$\begin{array}{l}\text { Environment } \\
\text { and Special } \\
\text { Services }\end{array}$} & $\begin{array}{l}\text { Involve the } \\
\text { community in } \\
\text { the } \\
\text { implementation } \\
\text { of inclusive } \\
\text { education. }\end{array}$ & $\sqrt{ }$ & & \\
\hline & & $\begin{array}{ll}\text { Special } & \text { service } \\
\text { of } & \text { special } \\
\text { needs students. }\end{array}$ & $\sqrt{ }$ & & \\
\hline
\end{tabular}

\section{B. Interview Results}

1. Implementation of Al-Islam and Kemuhammadiyahan Learning for Special Needs Students

a. Lecturer

As one of the universities that accept students with special needs and based on observations, UMJ does not specify a special quota for the acceptance of special needs students. The special needs students who enrolled in UMJ until now are students with visually impaired or blindness. This is based on the narrative of Informant 1:

"Until now, there are no other students of special needs than blind or visually impaired. Some had broken legs, but that was not too long, just by accident. A month, two months can get well again." (Informan 1)

The method used in the AIK teaching process is similar to other students who do not have special needs. In addition, at UMJ, especially in some faculty who accepted special needs students, does not specify syllabus or special matherial for special needs students. So the learning process passed by special needs 
students was similar with other students in general.

The design of the curriculum designed by some faculty who accepted the special needs students has been adjusted to the existing regulations. Changes is not possible because the number of special needs students in UMJ is still a minority, the number is less than the students who do not have special needs. The narrative of informant 1 and informant 2 is shown below:

"For the curriculum, syllabus, it's been designed from the beginning and yes it is. Here we do not distinguish either special needs students or regular students. The most prominent difference is in the learning process, for special needs students assisted by shadow friends, so that helps them everywhere, even help learn as well. "(Informant 1)

"We consider special needs students and regular students are the same, it's just that they (special needs students) have limitations whereas ordinary students do not. But there is a friend of shadow, because basically they can not see, so to help them interpret the course, AIK for example. Special needs students who registered here also know that our policy accept them so. So for the curriculum and all the learning process are the same. "(Informant 2)

\section{b.Special Needs Student}

Special needs students enrolled in UMJ have several reasons, one of which is that they feel they have rights as stated in Act Number 20 Year 2003 regarding National Education System and Regulation of the Minister of National Education Number 70 Year 2009 on Inclusive Education. This policy allows people with disabilities to access education together with general students, according to the ability of persons with disabilities. Special needs students also consider that the education system at UMJ is certainly different from other universities in general, one of them because there is an AIK courses that make them in addition to be professional also proficient in religious ability.

By having a physical condition that is limited and different from other students, special needs students who are at UMJ still not discouraged and still learn like a student in general. If there is material from AIK lessons they do not yet understand, they try to ask their shadow friends or try to find their own through the internet that they normally use. Here are the results of interviews with some special needs students:

"During this time I still sometimes choose to use hp because college is not every day, and I live with my parents, not stay near university, so I am a little afraid of being a trouble if I depends on friends" (Informant 3)

"In understanding the material I personall, alhamdulillah, quite though sometimes late, because sometimes there are lecturers who explain the material use PPT and it do not read all by the lecturers, so I learn with a shadow friend where stayed close to me." (Informant 4)

c. Shadow Friend

In AIK learning process at UMJ, other students as good friends feel obliged to help each other. So they mutually and indiscriminately in helping their fellow students both the special needs students and non-special needs students. Even some of the students felt that by helping special needs students, they were like repeating the material they had previously learned, so that when they had to take the exam they would just simply repeat it. Here are the results of interviews with non-crew students who act as shadow friends.

"Because we are non special needs students so to help those who are special needs students does not matter, we just like learning again so fitting the exam so it's easier not to learn all the material as a whole again." (Informant 5)

\section{The Role Shadow Friend in AIK Learning Process at UMJ}

a. Lecturer

The existence of a shadow friend for special needs students is considered very positive role according to lecturers and academic community in UMJ. Before a shadow friend, special needs students have more sensitive nature in socializing, in addition they also have a temperament that is quick to anger and impatient in facing anything including in AIK lectures and learning in the classroom. Since the presence of a shadow friend who helped their learning process and also their daily life at UMJ campus, they become more open minded person. Here is the interview with one of the lecturers:

"Wow very helpful once there is shadow friend. Shadow friends' role is different 
from other friends, if the shadow friends here that they specifically help special needs students in learning. If other ordinary friends are for example in the cafeteria, they help guide or show the way while their shadow buddies are scheduled and take turns to help learn. So special needs students feel very helpful, and their GPA also changed from the initially less and being better even though there is no prominent."

\section{b.Special Needs Student}

For special needs students, the presence of shadow friends is also very helpful. In terms of AIK learning assessment, they feel that they have improved both in value and spirit. In addition they feel more open in socializing and feel not ostracized because of the limitations they have.

\section{c. Shadow Friend}

Non-special needs students as shadow friends feel grateful to be a shadow friend for special needs students. They have their own pride because they can help special needs students as fellow human beings.

\section{DISCUSSION}

There are several steps that must be passed in the planning of learning and organizing special needs students. The stages include the following activities: (a) determine the areas or aspects of the learning problem to be addressed, whether the whole subject, some subject or only part of a subject, (b) establish the learning approach to be selected including the plan student organizing, whether the form is remedial lessons, the addition of in-class or out-of-class exercises, co-operative or competitive approaches, (c) organizing individualized learning programs. Individual learning programs (PPIs) are structured for students to learn/have problems obtaining education services according to their specific needs[5].

Implementation of learning AIK should be adjusted to the development of special needs students and can not be forced (flexible). Because learning is the interest of learners and not the interest of teachers or lecturers. If the implementation ignore their ability, then they will not grow liveliness, motivation, and creativity in learning. Based on the development and ability of special needs students, the learning of AIK can be done well and set goals can be achieved. The learning implementation plan is a guide that should be used in the learning process, because learning process has been set learning objectives, learning materials, learning activities, and assessment of learning (Lapono et al, 2008).[6]

Implementation of AIK at UMJ for special needs students is very important in improving their knowledge and religion. Their AIK learning process in addition to assisted by lecturers, they are also assisted by other non special needs students as a shadow friend. Based on the observations, from some educational components that are observed, there is no special quota in the acceptance of special needs students and the number of special needs students at UMJ is still a minority. In the process of identification and assessment or assessment including facilities and infrastructure, special needs students are equated with other students.

As for the learning, special needs students are not guided by special supervisors but assisted by other non special needs students as a shadow friend. The presence of shadow friends is very helpful for the development of special needs students both in terms of AIK assessment and in social life. This is in line with those disclosed by Schmidt \& Vrhovnik (2015), which says that what is more important and directly applicable to teachers to realize inclusive education is to create a cooperative learning environment. Cooperative Learning enables students to practice mutual understanding of each of their peers and care about the weaknesses of their classmates[7]. In the end this cooperative learning atmosphere is expected not only to create individual brain intelligence, but also to sharpen the intelligence and social sensitivity of both special needs students and non special needs students[8].

\section{CONCLUSION}

University of Muhammadiyah Jakarta as a university in the Muhammadiyah affiliation, including one of the institutions that accept special needs students in several faculties. The formulation of Muhammadiyah ideology and personality that became the breath in the development of Al Islam and Kemuhammadiyahan studies (AIK) at UMJ has been very in line with the spirit of PP No. 55 of 2007, and responded positively by UMJ, by giving AIK courses, which are not oriented as media to print religious experts, but to deliver students into Islamic professionals. They are not required to be religious scholars, but also have a commitment to practice religion, not only in the context of ritual acts, but insertion of code of conduct, spirit and Islamic values on professional behavior and social.

As for the learning, special needs students are not guided by special supervisors but assisted by other non special needs students as a shadow friend. The presence of shadow friends is very helpful for the development of special needs students both in terms of AIK assessment and in social life.

\section{REFERENCES}

[1] R. of I. Ministry of Health, "INFODATIN," Pusat Data dan Informasi Kementerian Kesehatan RI, Jakarta, 2014.

[2] D. P. Hallahan and J. M. Kauffman, Exceptional Children: An Introduction to Special Education, 10th ed. Boston: Pearson, 2006.

[3] A. et al, "Implementasi Kurikulum Al-Islam dan Kemuhammadiyahan (AIK) Melalui Model Student Centered Learning (SCL) di Program Studi Pendidikan Dokter Fakultas Kedokteran dan Kesehatan Universitas Muhammadiyah Jakarta," Ta'dibuna, vol. 3, 2014 
[4] L. J. Moleong, Metode Penelitian Kualitatif. Bandung: PT Remaja Rosda Karya, 2011.

[5] Y. Munawir dkk, Pendidikan bagi Anak dengan Problema Belajar. Solo: Tiga Serangkai, 2003.

[6] N. L. et al, Belajar dan Pembelajaran SD. Jakarta: Direktorat Jenderal Pendidikan Tinggi Departemen Pendidikan Nasional, 2008.

[7] M. Schmidt and K. Vrhovnik, "Attitudes Of Teachers Towards The Inclusion Of Children With Special Needs In Primary And Secondary Schools," Hrvat. Rev. Za Rehabil. Istraz., vol. 2, no. 51, pp. 16-30, 2015.

[8] K. W. Nolan, M. Orlando, and G. S. Liptak, "Care Coordination Services for Children With Special Health Care Needs: Are We Family-Centered Yet? Families, Systems, and Health,” vol. 3, no. 25, pp. 293-306, 2007. 